\title{
The effect of zirconium oxide nanoparticles on dehydrogenase and hydrolytic activity of activated sludge microorganisms
}

\author{
Nina Doskocz ${ }^{1, ~}{ }^{*}$, Katarzyna Affek ${ }^{1}$, and Monika Załęska-Radziwiłł ${ }^{1}$ \\ ${ }^{1}$ Warsaw University of Technology, Faculty of Building Services, Hydro and Environmental \\ Engineering, Department of Biology, Nowowiejska 20, 00-653 Warsaw, Poland
}

\begin{abstract}
The pervasive use of engineered nanoparticles (NPs) in a wide range of fields raises concerns about their potential environmental impacts. The impact of NPs on the activity of enzymes in sewage sludge was examined using model engineered zirconium oxide nanoparticles (nano- $\mathrm{ZrO}_{2}$ ). Dehydrogenase activity was evaluated with the TTC test and hydrolytic activity with FDA test. In this study an inhibitory or a stimulating effect of NPs on the activity of the enzymes was observed. The levels of inhibition/stimulation of the nano- $\mathrm{ZrO}_{2}$ varied in relation to duration of contact NPs with activated sludge and particle size (nano, bulk).
\end{abstract}

\section{Introduction}

Due to the intensive development of nanotechnology, more and more engineered nanoparticles (NPs) have been widely used in many industrial and consumer products as a result they are released into and spread in the environment [1-2]. Many types of NPs have already been found in soils, surface waters, wastewaters, and sewage sludge, therefore, the potential environmental impacts of the released nanoparticles attract much attention [3], however great controversy still exists on the effects of nanoparticle on biological wastewater treatment processes and a toxicology model has not been built yet [4].

Considerable attention has been paid to the potential adverse effects on biological wastewater treatment system due to the antimicrobial properties of silver nanoparticles. [5-8]. However, have been relatively few studies on the effect of NPs on the activity of enzymes which may be indicators of the functioning of microorganisms involved in biological wastewater treatment. In Zheng research, it was found that long term exposure to $\mathrm{Al}_{2} \mathrm{O}_{3}, \mathrm{SiO}_{2}, \mathrm{TiO}_{2}$, and $\mathrm{ZnO}$ NPs significantly affected the microbial communities and changed the relative abundances of key functional bacteria, such as ammonia-oxidizing bacteria. Also, the gene expressions and catalytic activities of essential enzymes, such as ammonia monooxygenase, nitrite

*Corresponding author: nina.doskocz@pw.edu.pl 
oxidoreductase, nitrate reductase, and nitrite reductase, were decreased, which finally resulted in a lower efficiency of biological nitrogen removal [1].

Biological oxidation of organic compounds by living bacterial cells is done mainly with the participation of enzymes from the class oxidoreductases, which belongs to dehydrogenases. Determination of dehydrogenase activity is a principal element in determining the state of microorganisms during aerobic metabolism [9], because dysfunction of the enzymatic activity of activated sludge (which is the most widely used wastewater treatment option), may disturb the biological removal of pollutants, which may have ecological and economic consequences. Therefore, the present study aimed at assessing the effect of zirconium oxide nanoparticles on enzymatic activity of activated sludge microorganisms. Because nanoparticles have some different properties (such as: high surface to volume ratio, a high chemical reactivity, an ability to form aggregates, diffusivity, and mechanical strength) compared to their bulk counterparts, in this paper the influence of bulk form of zirconium oxide on enzymatic activity has been also examined.

The interest in the nanocompound chosen results from the fact that its influence on microorganisms from activated sludge is virtually unknown.

Zirconium oxide nanoparticles (nano- $\mathrm{ZrO}_{2}$ ) are used to eliminate the pollution of water, inter alia the arsenic, as a catalyst and in bioengineering - in the production of prostheses and implants as well as the carriers of medicines (insulin) [10, 11]. More and more common use of these nanoparticles can be the cause of their release to the environment and induction of toxic reactions in the organisms of aquatic ecosystems.

\section{Materials and methods}

\subsection{Chemicals}

Zirconium oxide nanoparticles (nano- $\mathrm{ZrO}_{2}$ ), nanopowder $<100 \mathrm{~nm}$ with a specific surface area $\geq 25 \mathrm{~m}^{2} / \mathrm{g}$ and zirconium oxides of purity over $98 \%$ were obtained from Sigma-Aldrich. CAS no. of compounds containing $\mathrm{ZrO}_{2}$ is 1314-23-4. The stock solutions of nanocompounds and oxides with a concentration of $500 \mathrm{mg} / \mathrm{l}$ were prepared in deionized water. To avoid formation of the aggregates, the stock dispersion was sonicated $(0.4 \mathrm{~kW}, 20 \mathrm{kHz})$ for $30 \mathrm{~min}$ before being diluted to the exposure concentrations. The stock solutions were diluted in descending order with a geometric series of quotient $\mathrm{q}=2$ to obtain final concentrations of 500-0.97 mg/l.

\subsection{Determination of enzymatic activity}

Enzymatic activity of the microorganisms in the presence of tested compounds was determined by means of the triphenyl tetrazolium chloride (TTC) test for dehydrogenases activity and test for hydrolytic activity - fluorescein diacetate (FDA) determination. The TTC test was performed in accordance with the Polish Standard PN-C-04616-8 2008. Specific enzyme activity was estimated in a spectrophotometer at $490 \mathrm{~nm}$ by measuring the concentration of triphenyl formazan (TF) formed from TTC reduction.

Determination of TTC dehydrogenase activity was made as follows: introduced into tubes a suspension of bacterial cells in a volume of $5 \mathrm{ml}$. The cell suspension was prepared by inoculating $100 \mathrm{ml}$ of broth medium with $0.5 \mathrm{ml}$ of activated sludge after incubation with test compounds after $30 \mathrm{~min}$. and $24 \mathrm{~h}$. The cultures were incubated 
at $26^{\circ} \mathrm{C}$ in $48 \mathrm{~h}$. After incubation, the cultures were centrifuged and suspended in buffered water. $7 \mathrm{~mL}$ Tris- $\mathrm{HCl}$ buffer, $1 \mathrm{ml} \mathrm{Na} \mathrm{SO}_{3}(0.36 \%)$ were added into each tube. Incubation was carried out at $37^{\circ} \mathrm{C}$ under shaking conditions $(120 \mathrm{rpm})$ in the dark for $30 \mathrm{~min} .2 \mathrm{ml}$ sulfuric acid was added to terminate enzyme reaction. $10 \mathrm{ml}$ of butanol was added to the samples, mixed thoroughly and placed in a water bath with a temperature of $90^{\circ} \mathrm{C}$ for $5 \mathrm{~min}$. Then $5 \mathrm{ml}$ of butanol extract from each tube were centrifuged at $6000 \mathrm{rpm}$ for $5 \mathrm{~min}$. The TF was measured at $490 \mathrm{~nm}$ in the spectrophotometer. The results were given in $\mu \mathrm{mol}$ of TF per s and $\mathrm{kg}$ of dry weight (d.w.) [12].

The FDA test was performed in accordance with the Schnürer and Rosswall method [13]. The bacterial suspensions in the phosphate buffer ( $\mathrm{pH} 7.6)$ with FDA in acetone $\left(20 \mathrm{mg} \mathrm{cm}^{-3}\right)$ were incubated at $26^{\circ} \mathrm{C}$ under shaking conditions. The enzymatic reaction was stopped by the addition of acetone in a volume ratio of $1: 1$. The concentration of produced fluorescein was determined spectrophotometrically at $490 \mathrm{~nm}$. The enzymatic activity is reported as $\mathrm{mg}$ of fluorescein $\mathrm{s}^{-1} \mathrm{~g}^{-1} \mathrm{~d}$.w. [14].

To perform TTC and FDA tests the appropriate chemicals and activated sludge working in laboratory conditions, in Department of Biology, Faculty of Building Services, Hydro and Environmental Engineering, Warsaw University of Technology were used.

Assessment of inhibition dehydrogenase and hydrolase activity was made after 30 min and 24 hours of activated sludge incubation with the tested compounds. Each experiment was done in 3 replicates. The mean values and standard deviations were then calculated for each experimental group exposed to tested compounds. Samples containing activated sludge that had not previously been treated with the test compounds were used as control. To clear the presentation of the results, the enzyme activity data of treated activated sludge samples were expressed as the percentage of the enzyme activity compared to the control sample.

Inhibition of enzymatic activity was calculated according to Eq. 1.

$$
I=\frac{B_{c}-B_{n}}{B_{c}} \cdot 100[\%]
$$

$\mathrm{I}_{\mathrm{c}}-$ Inhibition of enzymatic activity

$\mathrm{B}_{\mathrm{c}}$ - Optical density of suspension in control sample after time $t$

$\mathrm{B}_{\mathrm{n}}-$ Optical density of suspension in the sample examined after time $\mathrm{t}$

\section{Results}

The concentration of the zirconium oxide nanoparticles influenced the enzyme activity of the activated sludge, but that effect was strongly diversified. This was determined by the kind of the tested particles and type of enzymatic activity (dehydrogenase activity and hydrolytic activity). Table 1 and 2 presents dehydrogenase and hydrolytic activity in the presence of nano- $\mathrm{ZrO}_{2}$ and their bulk counterparts. Figure 1-4 presents the percentage of inhibition/stimulation of enzymatic activities depending on the concentration and type of tested compounds.

The activity dehydrogenase in samples with nano- $\mathrm{ZrO}_{2}$ after 30 minutes decreased with increasing concentration and ranged from 102.9 to almost $58.4 \mu \mathrm{mol} \mathrm{TF} / \mathrm{kg}$ d.w. $\mathrm{s}^{-1}$. After 24 hours cellular respiration examined by TTC method decreased with increasing concentration of tested NPs and was from 56.2 to $122.6 \mu \mathrm{mol} \mathrm{TF} / \mathrm{kg}$ d.w. $\mathrm{s}^{-1}$ (table 1). 
Nano- $\mathrm{ZrO}_{2}$ after 30 min strongly inhibited dehydrogenase activity. A stimulating effect appeared only at the concentrations of 15.6 and $0.97 \mathrm{mg} / \mathrm{l}$ nano- $-\mathrm{ZrO}_{2}$. In activated sludge, nano- $\mathrm{ZrO}_{2}$ in concentrations of $500-31.3 \mathrm{mg} / \mathrm{l}$ after $24 \mathrm{~h}$ in the higher concentrations stimulated the activity of that enzyme (41.33-13.66\%). An inhibiting effect was observed in the lower tested concentrations of NPs (figure 1).

Decreased of hydrolytic activity in activated sludge with nano- $\mathrm{ZrO}_{2}$ in all tested concentrations in relation to control was observed regardless of the duration of the test (table 1), consequently this NPs caused a clear stimulation of the activity of hydrolytic enzymes in microorganisms of activated sludge (figure 3 ).

The obtained results also show that the bulk forms of tested nanoparticles a different impact on dehydrogenase and hydrolytic activities (table 2). Zirconium oxide lesser extent inhibited dehydrogenase activity as well as and less stimulated hydrolytic activity than nano- $\mathrm{ZrO}_{2}$ (figure 2 and 4 ).

Table 1. Dehydrogenase and hydrolytic activity in the presence of nano- $\mathrm{ZrO}_{2}$.

\begin{tabular}{|c|c|c|c|c|c|}
\hline \multirow{2}{*}{ 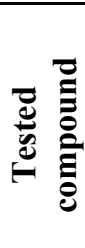 } & \multirow{2}{*}{ 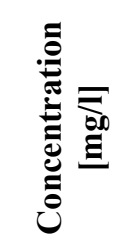 } & \multicolumn{2}{|c|}{ 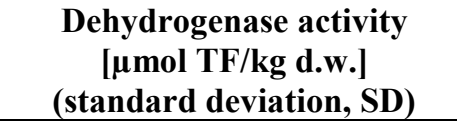 } & \multicolumn{2}{|c|}{$\begin{array}{c}\text { Hydrolytic activity } \\
{\left[\mu \mathrm{g} \text { fluorescein/kg of d.w. } \mathrm{s}^{-1} \text { ] }\right.} \\
\text { (standard deviation, SD) }^{\text {(stand }}\end{array}$} \\
\hline & & after $30 \mathrm{~min}$ & after $24 \mathrm{~h}$ & after $30 \mathrm{~min}$ & after $24 \mathrm{~h}$ \\
\hline \multirow{11}{*}{ 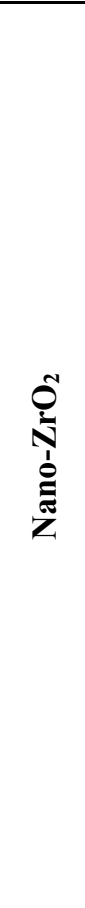 } & 500 & $\begin{array}{c}102.9 \\
(101.4-103.3) \\
\end{array}$ & $\begin{array}{c}56.2 \\
(53.1-56.6) \\
\end{array}$ & $\begin{array}{c}363.7 \\
(365.4-363.3) \\
\end{array}$ & $\begin{array}{c}11.4 \\
(11.9-12.5) \\
\end{array}$ \\
\hline & 250 & $\begin{array}{c}98.3 \\
(99.1-99.6)\end{array}$ & $\begin{array}{c}56.9 \\
(56.5-57.2)\end{array}$ & $\begin{array}{c}349.3 \\
(350.1-349.8)\end{array}$ & $\begin{array}{c}9.8 \\
(9.5-9.5)\end{array}$ \\
\hline & 125 & $\begin{array}{c}87.4 \\
(87.1-89.3) \\
\end{array}$ & $\begin{array}{c}59.2 \\
(59.1-60.9) \\
\end{array}$ & $\begin{array}{c}341.2 \\
(111.4-109.3)\end{array}$ & $\begin{array}{c}9.4 \\
(9.9-10.1)\end{array}$ \\
\hline & 62.5 & $\begin{array}{c}85.4 \\
(83.3-85.5) \\
\end{array}$ & $\begin{array}{c}60.5 \\
(60.4-59.5) \\
\end{array}$ & $\begin{array}{c}285.8 \\
(286.4-286.3)\end{array}$ & $\begin{array}{c}8.6 \\
(8.4-8.7) \\
\end{array}$ \\
\hline & 31 & $\begin{array}{c}84.9 \\
(84.4-85.1)\end{array}$ & $\begin{array}{c}62.3 \\
(63.1-61.9)\end{array}$ & $\begin{array}{c}239.8 \\
(241.1-238.9)\end{array}$ & $\begin{array}{c}8.5 \\
(9.5-8.1)\end{array}$ \\
\hline & 15 & $\begin{array}{c}72.9 \\
(73.5-72.7)\end{array}$ & $\begin{array}{c}69.5 \\
(69.7-69.7)\end{array}$ & $\begin{array}{c}232.3 \\
(232.7-233.6)\end{array}$ & $\begin{array}{c}8.3 \\
(8.9-8.2)\end{array}$ \\
\hline & 7.8 & $\begin{array}{c}70.6 \\
(73.0-69.6) \\
\end{array}$ & $\begin{array}{c}78.3 \\
(53.1-59.6) \\
\end{array}$ & $\begin{array}{c}131.0 \\
(132.2-132.7)\end{array}$ & $\begin{array}{c}7.8 \\
(8.7-7.4) \\
\end{array}$ \\
\hline & 3.9 & $\begin{array}{c}66.5 \\
(65.9-67.3) \\
\end{array}$ & $\begin{array}{c}80.8 \\
(80.5-79.0) \\
\end{array}$ & $\begin{array}{c}62.7 \\
(63.6-62.8) \\
\end{array}$ & $\begin{array}{c}6.3 \\
(6.6-7.6) \\
\end{array}$ \\
\hline & 1.9 & $\begin{array}{c}59.9 \\
(53.1-59.6) \\
\end{array}$ & $\begin{array}{c}87.9 \\
(86.5-89.1) \\
\end{array}$ & $\begin{array}{c}58.5 \\
(58.4-58.2) \\
\end{array}$ & $\begin{array}{c}5.8 \\
(5.9-4.5) \\
\end{array}$ \\
\hline & 0.97 & $\begin{array}{c}58.4 \\
(58.4-59.5)\end{array}$ & $\begin{array}{c}122.6 \\
(123.7-122.4)\end{array}$ & $\begin{array}{c}33.7 \\
(33.9-34.5)\end{array}$ & $\begin{array}{c}4.9 \\
(3.9-4.6)\end{array}$ \\
\hline & Control & $\begin{array}{c}43.3 \\
(43.1-44.7)\end{array}$ & $\begin{array}{c}65.1 \\
(63.1-64.1)\end{array}$ & $\begin{array}{c}15.5 \\
(15.8-15.5)\end{array}$ & $\begin{array}{c}0.5 \\
(0.9-0.1)\end{array}$ \\
\hline
\end{tabular}


Table 2. Dehydrogenase and hydrolytic activity in the presence of $\mathrm{ZrO}_{2}$.

\begin{tabular}{|c|c|c|c|c|c|}
\hline \multirow{2}{*}{ 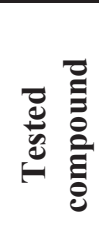 } & \multirow{2}{*}{ 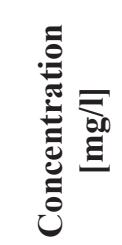 } & \multicolumn{2}{|c|}{ 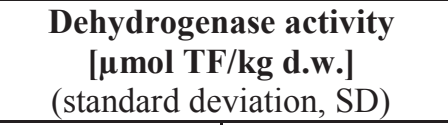 } & \multicolumn{2}{|c|}{$\begin{array}{c}\text { Hydrolytic activity } \\
\text { [ } \boldsymbol{\mu g} \text { fluorescein/kg of } \mathbf{d} . \mathbf{w} . \mathbf{s}^{-1} \text { ] } \\
\text { (standard deviation, SD) }\end{array}$} \\
\hline & & after $30 \mathrm{~min}$ & after $24 \mathrm{~h}$ & after $30 \mathrm{~min}$ & after $24 \mathrm{~h}$ \\
\hline \multirow{11}{*}{ อ๊ } & 500 & $\begin{array}{c}92.3 \\
(93.1-89.6) \\
\end{array}$ & $\begin{array}{c}36.0 \\
(36.5-37.1) \\
\end{array}$ & $\begin{array}{c}464.6 \\
(464.4-465.3) \\
\end{array}$ & $\begin{array}{c}19.4 \\
(19.5-19.3) \\
\end{array}$ \\
\hline & 250 & $\begin{array}{c}80.2 \\
(81.4-79.7) \\
\end{array}$ & $\begin{array}{c}46.8 \\
(49.1-46.8) \\
\end{array}$ & $\begin{array}{c}448.5 \\
(449.5-449.9) \\
\end{array}$ & $\begin{array}{c}19.1 \\
(19.2-20.8) \\
\end{array}$ \\
\hline & 125 & $\begin{array}{c}57.5 \\
(59.5-58.2) \\
\end{array}$ & $\begin{array}{c}49.2 \\
(49.5-48.8) \\
\end{array}$ & $\begin{array}{c}441.8 \\
(441.3-441.6) \\
\end{array}$ & $\begin{array}{c}16.2 \\
(17.1-16.9) \\
\end{array}$ \\
\hline & 62.5 & $\begin{array}{c}57.3 \\
(57.9-57.5) \\
\end{array}$ & $\begin{array}{c}50.9 \\
(49.8-48.2) \\
\end{array}$ & $\begin{array}{c}394.8 \\
(394.7-395.6)\end{array}$ & $\begin{array}{c}14.9 \\
(13.9-14.7) \\
\end{array}$ \\
\hline & 31.3 & $\begin{array}{c}54.4 \\
(54.7-54.9) \\
\end{array}$ & $\begin{array}{c}52.9 \\
(39.5-38.8) \\
\end{array}$ & $\begin{array}{c}367.4 \\
(368.0-366.1) \\
\end{array}$ & $\begin{array}{c}11.1 \\
(11.6-10.3) \\
\end{array}$ \\
\hline & 15.6 & $\begin{array}{c}52.8 \\
(51.9-53.0) \\
\end{array}$ & $\begin{array}{c}64.1 \\
(61.5-64.7) \\
\end{array}$ & $\begin{array}{c}332.9 \\
(331.4-331.8)\end{array}$ & $\begin{array}{c}10.2 \\
(9.5-11.1)\end{array}$ \\
\hline & 7.8 & $\begin{array}{c}50.4 \\
(50.5-51.2) \\
\end{array}$ & $\begin{array}{c}71.1 \\
(71.0-72.9) \\
\end{array}$ & $\begin{array}{c}238.3 \\
(240.8-237.6) \\
\end{array}$ & $\begin{array}{c}8.2 \\
(8.4-9.5) \\
\end{array}$ \\
\hline & 3.9 & $\begin{array}{c}46.7 \\
(49.5-45.1) \\
\end{array}$ & $\begin{array}{c}78.6 \\
(78.4-79.1) \\
\end{array}$ & $\begin{array}{c}87.2 \\
(88.4-89.1) \\
\end{array}$ & $\begin{array}{c}7.0 \\
(7.7-8.1) \\
\end{array}$ \\
\hline & 1.9 & $\begin{array}{c}39.9 \\
(39.5-38.8) \\
\end{array}$ & $\begin{array}{c}78.9 \\
(78.6-79.4) \\
\end{array}$ & $\begin{array}{c}69.9 \\
(69.6-70.4) \\
\end{array}$ & $\begin{array}{c}6.8 \\
(6.5-6.7) \\
\end{array}$ \\
\hline & 0.97 & $\begin{array}{c}36.7 \\
(56.6-36.0) \\
\end{array}$ & $\begin{array}{c}111.2 \\
(111.4-109.3) \\
\end{array}$ & $\begin{array}{c}44.2 \\
(43.2-44.9) \\
\end{array}$ & $\begin{array}{c}5.4 \\
(5.5-9.5) \\
\end{array}$ \\
\hline & Control & $\begin{array}{c}42.3 \\
(42.5-41.3) \\
\end{array}$ & $\begin{array}{c}61.4 \\
(61.2-62.7) \\
\end{array}$ & $\begin{array}{c}17.1 \\
(17.6-17.5) \\
\end{array}$ & $\begin{array}{c}0.8 \\
(1.1-0.3)\end{array}$ \\
\hline
\end{tabular}

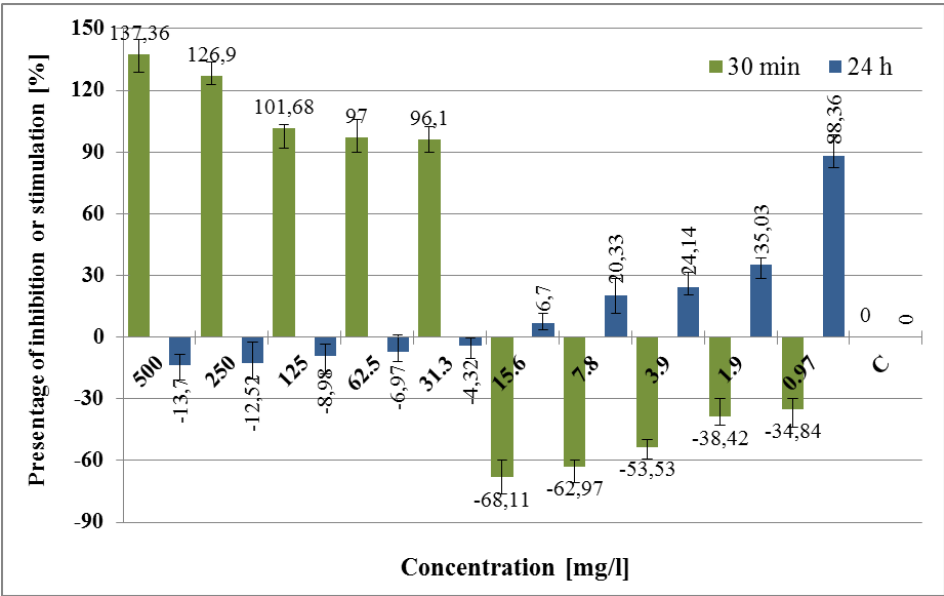

Fig. 1. Percentage of inhibition cellular respiration in TTC method in the presence of nano- $\mathrm{ZrO}_{2}$. 


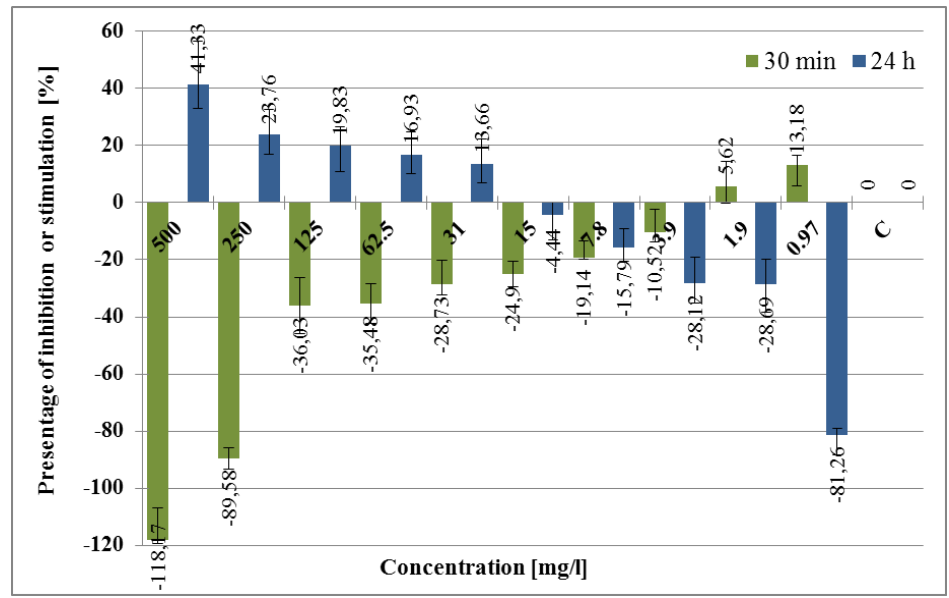

Fig. 2. Percentage of inhibition cellular respiration in $\mathrm{TTC}$ method in the presence of $\mathrm{ZrO}_{2}$.

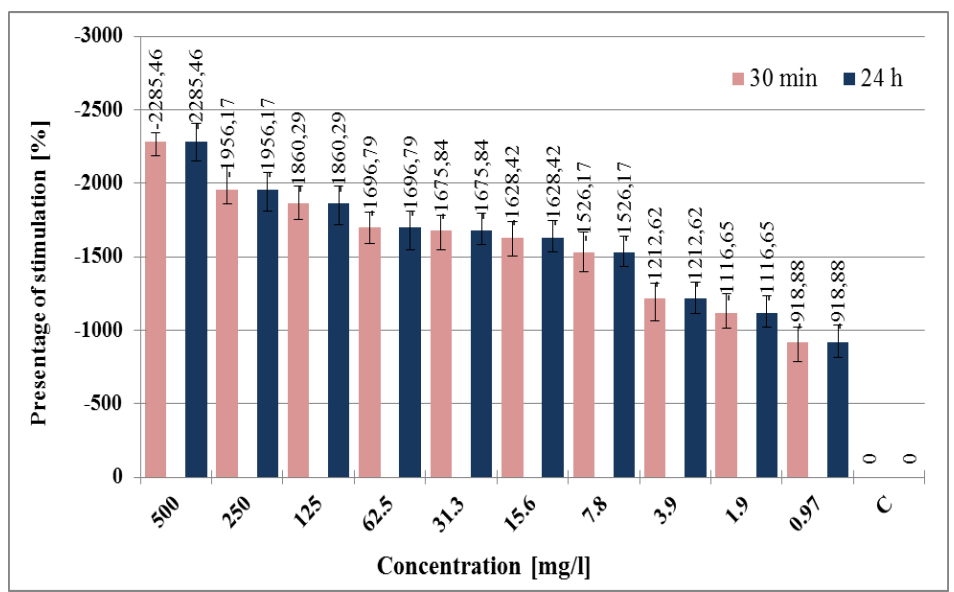

Fig. 3. Percentage of stimulation of hydrolytic activity in the presence of nano- $\mathrm{ZrO}_{2}$.

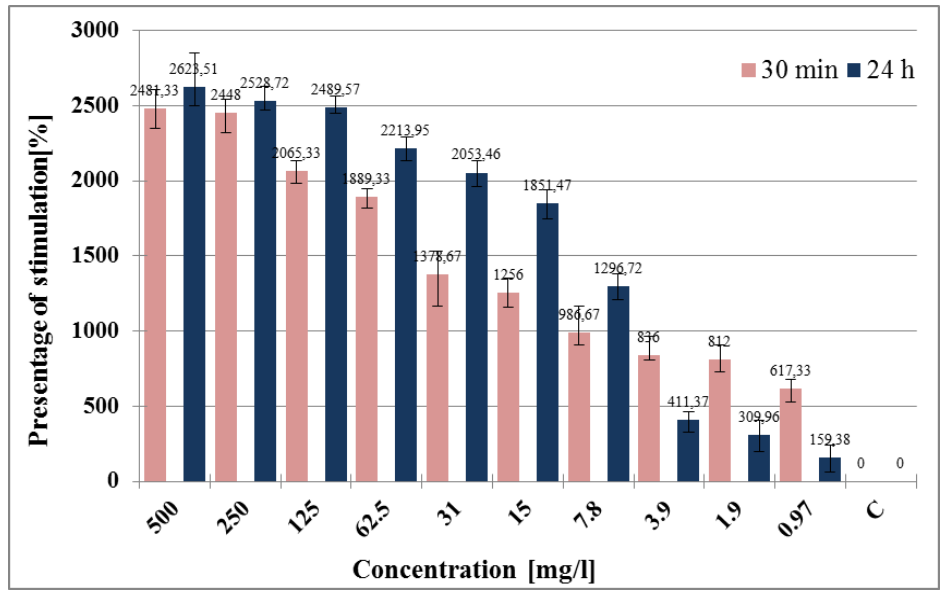

Fig. 4. Percentage of stimulation of hydrolytic activity in the presence of $\mathrm{ZrO}_{2}$. 


\section{Discussions}

Biological removal of pollutants depends on many biochemical reactions, which are catalyzed by some key enzymes in activated sludge microorganisms. However, to date, the influences of nanoparticles on the essential enzymes related to pollutant removal are infrequent [15-16].

The comparison of dehydrogenases' and hydrolytic activity between samples with activated sludge containing nano- $\mathrm{ZrO}_{2}$ and the control samples (activated sludge without NPs) proved that tested nanoparticles can influence on metabolism of the microorganisms involved in the biological wastewater treatment. After $24 \mathrm{~h}$, in five higher tested concentration of nano- $\mathrm{ZrO}_{2}$, cellular respiration examined by TTC method decrease suggesting biocidal properties of these nanoparticles. However, in most samples we observed increase enzyme activities. Stimulation of dehydrogenase and hydrolytic activity of microorganisms in activated sludge may be disadvantageous. May lead to an increased demand for oxygen in biomass biodegradation process and can lead to the formation of anaerobic zones. These results may suggest that the presence of nanoparticles might negatively influence the communities of microorganisms participating in biological processes. Kamika et al. (2017) research also showed that nanoparticles can inhibit the activity of enzymes. The impacts of cerium oxide nanoparticles on bacterial community in activated sludge shown a drastic reduction of activities for enzymes catalyzing denitrification (nitrate reductase and nitrite reductase) and degradation of polyphosphate (adenylate kinase and polyphosphate kinase) [17]. In turn, the studies of Chojniak et al. (2017) did not show decrease in respiratory activity by TTC assay, suggesting biocidal properties of Ag nanoparticles [18]. In turn, Kim et al. (2013), comparing the sensitivity of various enzymes to NPs, observed that dehydrogenase was more sensitive to nano- $\mathrm{CuO}$ than to nano- $\mathrm{ZnO}$ [19].

The results obtained in the study showed that impact of nano- $\mathrm{ZrO}_{2}$ on enzymatic activity was different than those observed for their bulk counterparts (table 2, figure 2 and 4). The literature data also indicate that nanoparticles may have other effects on the microorganisms from activated sludge than the same compounds in their bulk forms. It might be a result of many different properties of nanoparticles such as: high surface to volume ratio, high chemical reactivity, the ability to form aggregates, diffusivity, and mechanical strength. Moreover, nanoparticles due to their small size $(1-100 \mathrm{~nm})$ can penetrate the inside of an organism more easily than their bulk counterparts, where they can cause various types of dysfunction [20]. Different dehydrogenase activity in the presence of the nano- than the bulk form of $\mathrm{CuO}$ was also observed by Kim et al. (2011) in his research [21].

\section{Conclusions}

The conducted studies concerning the impact of aluminum oxide nanoparticles (nano- $\mathrm{ZrO}_{2}$ ) on the enzymatic activity on microorganisms of activated sludge allowed formulating the following conclusions: (1) Zirconium oxide nanoparticles inhibition cellular respiration in TTC method in the five highest tested concentrations after $30 \mathrm{~min}$ and in the five lowest tested concentrations after $24 \mathrm{~h}$. In the other samples observed increase dehydrogenase activity; (2) Nano- $\mathrm{ZrO}_{2}$ caused a clear stimulation of the activity of hydrolytic enzymes in microorganisms of activate sludge; (3) Effects of zirconium oxide $\left(\mathrm{ZrO}_{2}\right)$ on enzyme activity was different than in the case of the nano form of $\mathrm{ZrO}_{2}$. 
This research confirmed the data found in literary sources and showed that zirconium oxide nanoparticles might negatively influence on the enzyme activity of microorganisms participating in biological wastewater treatment, which indicates that this compound could affect wastewater nutrient removal.

It was found that nano forms of $\mathrm{ZrO}_{2}$ influences in a different way than their bulk counterparts. Therefore, available ecotoxicity data about compounds in bulk forms cannot be used to assess the harmfulness of their nano form

This study increased the ecotoxicological knowledge and database in relation to the effect of zirconium oxide nanoparticles on dehydrogenase and hydrolytic activity of microorganisms from activated sludge.

\section{References}

1. X. Zheng, H. Huang, Y. Su, Y. Wei, Y. Chen, Water Sci. Technol., 72, 99-105 (2015)

2. G.E. Batley, J.K. Kirby, M.J. McLaughlin, Acc. Chem. Res., 46, 854-862 (2013)

3. B. Nowack, T.D., Bucheli, Environ. Pollut. 150, 5-22 (2007)

4. Z. Sheng, J.D. Van Nostrand, J. Zhou, Y. Liu, J. Hazard. Mater., 341, 448-456 (2018)

5. X. Sun, Z. Sheng, Y. Liu, Sci. Total Environ., 443, 828-835 (2013)

6. Z. Liang, A. Das, Z. Hu, Water Res., 44, 5432-5438 (2010)

7. Y. Yang, M. Li, C. Michels, H. Moreira+Soares, P.J.J. Alvarez, Environ. Toxicol. Chem., 33, 2234-2239 (2014)

8. E. Jeong, W. Im, D. Kim, M. Kim, S. Kang, H. Shin, S. Chae, J. Environ. Sci. Heal. A, 49, 685-693 (2014)

9. S. Wuertz, P. Pfleiderer, K. Kriebitzsch, R. Späth, T. Griebe, P.A. Wilderer, H.C. Flemming, Water Sci. Technol., 37, 379-384 (1998)

10. M. Eshed, S. Pol, A. Gedanken, M. Balasubramanian,. Beilstein J. Nanotechnol., 2, 198-203 (2011)

11. A. Kaur, U. Gupta, J. Mater. Chem., 19, 8279-8289 (2009)

12. PN-C-04616-8 - Water and sewage - Special investigations of sludge - Part 8: Determination of dehydrogenase activity in activated sludge by spectrophotometric method with triphenyltetrazolium chloride, (2008)

13. J. Schnürer, J. Rosswall, Appl. Environ. Microbiol. 43, 1256-1261 (1982)

14. A. Tabernacka, E. Zborowska, K. Pogoda, M. Żołądek, Environ. Technol., doi: 10.1080/09593330.2017.1397759, (2017)

15. T. Mino, M.C.M. van Loosdrecht, J.J. Heijnen, Water Res., 32, 3193-3207 (1998)

16. R.J. Zeng, R. Lemaire, Z. Yuan, J. Keller, Biotechnol. Bioeng., 84, 170-178 (2003)

17. I. Kamika, M. Tekere, AMB Express., doi: 10.1186/s13568-017-0365-6, (2017)

18. J. Chojniak, I. Biedroń, G. Płaza, E3S Web of Conferences, 17, 1-8 (2017)

19. S. Kim, H. Sin, S. Lee, I. Lee, J. Microbiol. Biotechnol., 23, 1279-1286 (2013)

20. N. Chrzanowska, M. Załeska-Radziwiłł, Desalination Water Treat., 52, 3680-3689 (2014)

21. S. Kim, J. Kim, I. Lee, Chem. Ecol., 27, 49-55 (2011) 